\title{
The Influence of Natural Saline Solutions on Dihydrate Copper Chloride Crystallization
}

\author{
CRISTINA-DANIELA CIMPEAN ${ }^{1 *}$, MIHAI BERTEANU ${ }^{1,2}$ \\ ${ }^{1}$ Carol-Davila University of Medicine and Pharmacy, 8 Eroii Sanitari, Blvd., 050474, Bucharest, Romania \\ ${ }^{2}$ Elias Emergency University's Hospital, 17 Marasti Blvd., 011461, Bucharest, Romania
}

\begin{abstract}
The crystallization of salt solutions is strongly affected regarding the shape of the crystalline network by the presence of impurities, even in extremelly small quantities. This sensitivity is extremely high especially for dihydrate copper chloride (DCC) solution. The phenomenon is used for early diagnostic in medicine and for food quality assessment and named sensitive crystallization or biocrystallization. The evaluation is based on the morphology of the DCC network that crystallizes on a Petri plate containing a fine film of this solution to which a small amount of the substrate analyzed is added. For this reason, the understanding of the influence of all physico-chemical factors on the crystallization of the DCC solution is very important. To help elucidate some of these aspects, we analyzed by biocrystallization a series of 30 mineral waters from Romania, following their influence on the morphology of the DCC crystallization network. This is the first paper about biocrystallization of natural mineral waters. Following this analysis we noticed specific patterns generated by the predominant chemical composition and the total mineralization of the analyzed waters. These results can be extrapolated in the medical and agro-food field, contributing to the correct interpretation of the biocrystallisation test.
\end{abstract}

Keywords: biocrystallization, copper chloride, mineral waters

\section{Biocrystallisation test}

Typically, pure dehydrate copper chloride $\left(\mathrm{CuCl}_{2} \times 2 \mathrm{H}_{2} \mathrm{O}\right)$ crystallises orthorhombic in the form of fine needles, conglomerated in deposits [1] as we see in Figure 1. If a small amount of biological substance is added, a typical crystalline formation is completely inhibited; the crystal volume increases several thousand times [2] and appears as unspecific dendritic or curved forms. Crystalograms with reproducible dendritic textures are formed in this manner during crystallization [3]. The crystals formation is a combination of two processes: transport and attachment of diluted molecules to crystalline network. The resulted pattern is due to molecular interactions with the additive which influence or even directed the growth of crystals [4]. The remarkable variability of copper chloride crystal morphology forms the basis of its potential applications. The test is used in the food quality especially for differentiate the organic quality [5] and for medical purpose the most important is the early diagnosis of malignancy [6-9].

An experiment with an X-ray photo-electric spectroscopy of the copper chloride network derived from a solution containing human blood showed that the atoms in the added biological substrate (nitrogen, carbon or oxygen atoms) are absorbed at the surface of the copper chloride crystals, respectively, where there is a phenomenon of exchange of copper chlorine peripheral electrons, but they cannot be detected anywhere within the copper chloride crystals. In this experiment the conclusion was that these elements (nitrogen, carbon and oxygen) influence only the morphology of copper chloride crystallisation [2]. Another study realized in France showed that electric and magnetic fields have no influence on sensitive crystallisation or biocrystallisation [10].

Crystallisation image of DCC show differences in terms of experience. The most important parameters influencing image quality are evaporation rate and crystallisation time, ambient temperature, enclosure humidity, plate diameter, volume of copper chloride solution, the ratio between the added substrate and copper chloride [11-12]. Another interesting factor is dewetting (the retraction of the solution from the support) [13-14].

The crystallisation has two important elements: a nucleation and a growth process. Both parts of the phenomenon are influenced and controlled by thermodynamic parameters such as concentration or temperature, and can only occurred at concentrations higher than saturation concentration and at temperatures below the melting point. The most important influence of any additive is on the growth process [4].

All kinds of additive whether biological (vegetal, animal or human origin), simple or macromolecular chemical compounds can influence the crystallisation of cupric chloride. Acidic proteins play a role in nucleation or modulation of crystal morphology [15]. Proteins and polysaccharides have the greatest specific influence. The organic acids stimulate branching [16] and the amino-acids inhibit it [11]. In the presence of the polysaccharides the crystallograms have dendritic structures [16-19]. With proteins we can observes spherulitic crystals [6-9, 11, 20-21]. We have no data for observing the sensitive crystallization patterns in the presence of mineral waters.

*email: cimpean_cristina@yahoo.com 


\section{Experimental parts}

The mineral water samples

A number of 30 Romanian natural, mineral and medicinal waters were collected directly from the springs, in fully filled pet or glass containers to avoid water contact with air. All samples were analyzed with biocrystallization test in maximum seven days after collecting. These samples were Călimănești spring number 4, 5, 6, 7, 8 și 14; Căciulata spring 1 and 2; Herculane spring Neptun 3, Neptun 2, Scorillo, Hercule, Diana 3, Vicol; Micfalău spring 1 and 2; Băile Jigodin spring 1, 2 and 3; Malnaș spring Maria and Principal; Tușnad principal spring and Bagoly spring; Vâlcele principal spring and Elisabeta spring; Borsec spring 3, 5, 6, 10 and 11.

\section{Biocrystallization protocol}

For copper chloride dehydrate solution we used ACS, Reag. Ph. Eur. from Merck and bidistilled water obtained commercially. The additives used were the samples of mineral water.

The crystallization plates (Petri dishes of $8 \mathrm{~cm}$ diameter Anumbra) are preliminarily immersed for 24 hours in a solutions of phosphoric acid $5 \%$, rinsed repeatedly under cold water and finally in distilled water.

For each plates we prepared a solution with $0,07 \mathrm{~g}$ of DCC, $0,4 \mathrm{ml}$ of bidistilled water and $4,6 \mathrm{ml}$ of mineral water and for every samples we made a minimum of 4 plate.

The plates with solutions were kept for 14-18 hours in a crystallization chamber at a constant temperature of $30^{\circ}$ Celsius and a 53\% relative humidity. The crystallization chamber is a model inspired from [3, 12] permanently monitored for temperature and humidity. For ensured the evaporation we use a dehumidifier with a capacity of $250 \mathrm{ml}$ per day.

\section{Crystal images acquisition}

When the biocrystallization is finished the plates have been photographed by a Canon 550D, with lens 18-55 mm IS-STM, Canon Macro Lens EF 100mm f/2,8 USM and by using circular polarized filter Kenko.

\section{Digital images evaluation}

For blood testing the Pfeiffer or Selawry evaluation is used according to the individual case [22-23]. The patterns of biocrystallization for foods can be evaluated using standardized visual sensory analysis according ISO-Norms 11035 and 8587 or using different computerized image analysis tools [24-27]. Because of the high complexity of biocrystallization patterns, the visual evaluation is considered superior in discriminating differences between images [28]. The computerized analysis is based in fact on visual evaluation.

In accordance with ISO-Norms three laboratories, the Department of Food Quality and Food Culture at Kassel University of Germany, the Louis Bolk Institute in the Netherlands and the BRAD Byodinamic Research Associaton in Denmark, produced the standardization work of the method [5, 19, 28-31].

This is the first paper about the biocrystallization of mineral waters and in the literature has no data for a specific standardized evaluation, but the general panel established by Huber [28] and comprehensively developed by Doesburg [31] can be extrapolated with good reliability in the study of mineral waters biocrystallization. First it was necessary to form a standardized panel for sensory profiles according to ISO 11035 (1994) and then to adapt this norm for utilization in the visual evaluation of biocrystallization images [28] and after that ISO 8587 (2006): 'Sensory Analysis - Methodology - Ranking' was adapted for the development of a ranking measurement instrument for a global evaluation.

\section{Results and discussions}

The 30 mineral waters can be grouped in three basic categories according to chemical composition [32-34], as we see in table 1. These categories are hydrogen carbonated, calcic, magnesian, sodium waters $(\mathrm{CM})$, sulphurous, chlorine sodium, calcic waters (S) and chlorine sodium, calcic waters (CS). For these three groups we observed three main patterns (table 2).

The evaluation of crystalline patterns uses the notions of well or weak centred, coordination [35], structure and texture [11]. The crystalline structure refers to the main branches which depart from the centre to the periphery and the texture is formed by fine crystals which depart from main branches and form a more or less dense structure who cover up surface of plate.

The specific pattern for hydrogen carbonated, calcic, magnesian, sodium waters comparing with the specific pattern for DCC alone (Figure 1) is characterised by a very good centred and coordinated image (Figure 2a, b) with dendritic branches and a very good structure and texture (Figure 2c). We named this pattern specific dendritic pattern (SDP). These images have a very interesting and unexpected aspect because are similar to that of organic additives, and especially for flowers, leaves and aromatic herbs [36-37]. Also the tendency follow this pattern can be observed when herbs are growth in calcareous soil [37]. 
Table 1

MINERAL WATERS BASIC CATEGORIES

\begin{tabular}{|c|c|}
\hline Chemical characterisation & Mineral water spring \\
\hline $\begin{array}{l}\text { Hydrogen carbonated, calcic, } \\
\text { magnesian, sodium (CM) }\end{array}$ & $\begin{array}{c}\text { Borsec: } 3 \text { (B3), 5 (B5), } 6 \text { (B6), } 10(\mathrm{~B} 10), 11 \text { (B11) } \\
\text { Tușnad: principal (TP), Bagoly (TB) } \\
\text { Vălcele: principal (VP), Elisabeta (VE) } \\
\text { Micfalău: } 1 \text { (M1), } 2 \text { (M2) } \\
\text { Băile Jigodin: } 1 \text { (BJ1), } 2 \text { (BJ2), } 3 \text { (BJ3) } \\
\text { Malnaș: Maria (MM), principal (MP) }\end{array}$ \\
\hline $\begin{array}{l}\text { Sulphurous, chlorine sodium, } \\
\text { calcic (S) }\end{array}$ & $\begin{array}{c}\text { Callimănești 4(C4), 5 (C5), 6(C6), 8(C8) } \\
\text { Căciulata } 1(\mathrm{C} 1) \\
\text { Herculane: Neptun 2 (HN2), Neptun } 3(\mathrm{HN} 3), \text { Vicol (HV), Diana } 3 \\
\text { (HD3) }\end{array}$ \\
\hline Chlorine sodium, calcic (CS) & $\begin{array}{c}\text { Herculane: Hercules (HH), Scorillo (HS) } \\
\text { Căciulata: } 2(\mathrm{C} 2) \\
\text { Călimănești: } 14(\mathrm{C} 14), 7(\mathrm{C} 7)\end{array}$ \\
\hline
\end{tabular}

Table 2

SPECIFIC SENSITIVE CRYSTALLISATION PATTERNS FOR THE ANALYSED SAMPLES

\begin{tabular}{|c|c|c|c|c|}
\hline Mineral water spring & Chemical characterisation & \multicolumn{2}{|c|}{$\begin{array}{c}\text { Sensitive crystallisation pattern } \\
\text { (+ for present, - for absent) }\end{array}$} \\
\cline { 3 - 5 } & & SDP & SMP & SLCP \\
\hline $\begin{array}{c}\text { B3, B5, B6, B10, B11, TP, TB, } \\
\text { VP, VE, M1, M2, BJ1, BJ2, } \\
\text { BJ3, MM, MP }\end{array}$ & CM & & - & - \\
\hline $\begin{array}{c}\text { C1, C4, C5, C6, C8, HN2, } \\
\mathrm{HN} 3, \mathrm{HV}, \mathrm{HD} 3\end{array}$ & & & & \\
\hline $\mathrm{C} 2, \mathrm{HH}, \mathrm{HS}, \mathrm{C14}, \mathrm{C7}$ & S & - & + & - \\
\hline
\end{tabular}

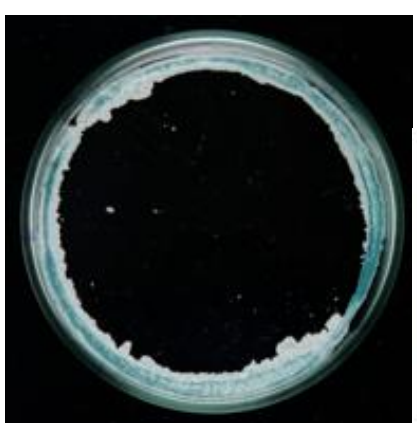

Fig. 1. Biocrystallization pattern for DCC alone, $0.07 \mathrm{~g}$ DCC/plate

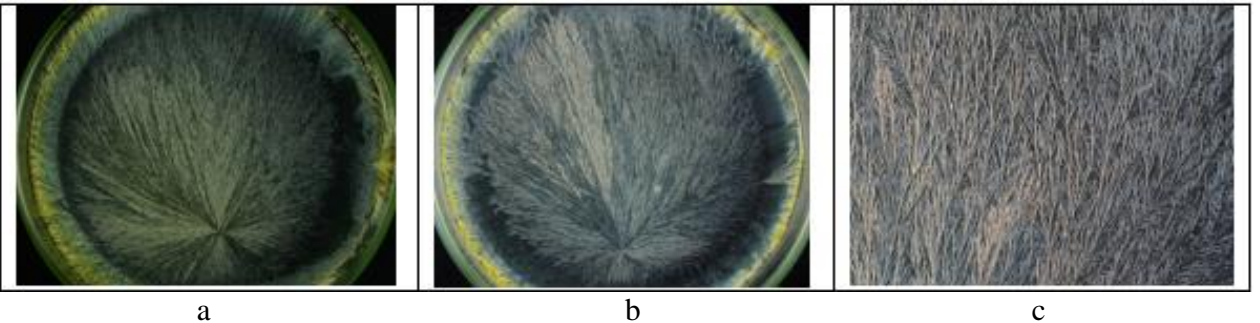

Fig. 2a. Specific dendritic pattern (SDP) for Valcele spring 1: $0.07 \mathrm{~g} / 4.6 \mathrm{ml} / 0.4 \mathrm{~mL}$ (DCC/mineral water/bidistilled water per plate); Fig. 2b. SDP for Borsec spring 6: 0.07 $\mathrm{g} / 4.6 \mathrm{~mL} / 0.4 \mathrm{~mL}$ (DCC/mineral water/bidistilled water per plate); Fig. 2c. detail Figure $2 \mathrm{~b}$

In case of sulphurous water we observed a very strong inhibition of any dendritical growth of the crystals. The image is multicenter, without coordination and the main themes is straight crystals formation star-shaped (Figure 3a, b, c) This appearance have some similarity to images for aminated acids especially the sulphated or thiol amino acids [11]. We named specific multicenter pattern (SMP).

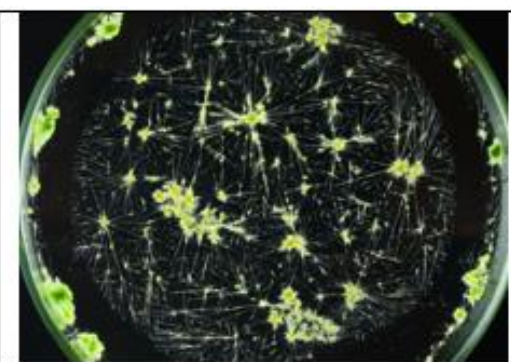

a

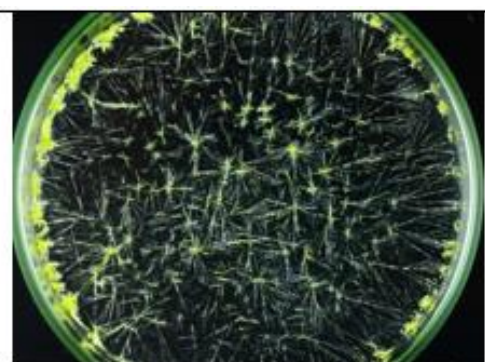

b

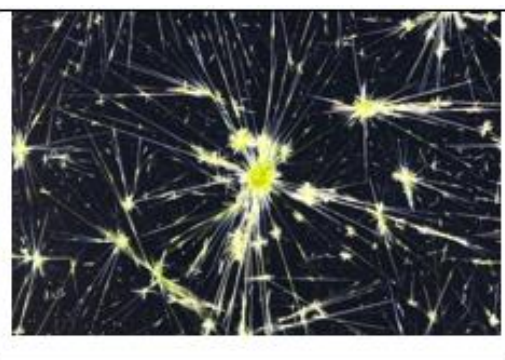

$\mathrm{c}$

Fig. 3a. Specific multicentric pattern (SMP) for Herculane - Neptun 2 spring; 0,07 g/4,6 mL/0.4 mL (DCC/mineral water/bidistilled water per plate; Fig. 3b. SMP for Căciulata - 1 spring; 0.07 g/4,6mL/0,4 mL (DCC/mineral water/bidistilled water per plate; Fig. 3c. detail Figure $3 \mathrm{a}$ 
For chlorine sodium and calcic waters the pattern can be centred but usually less coordinated (specific less coordinated pattern - SLCP). The structure and texture are weak individualised, the main branches are fragile, transparent, forming the structure similar to DCC alone (Figure $4 a, b, c)$.

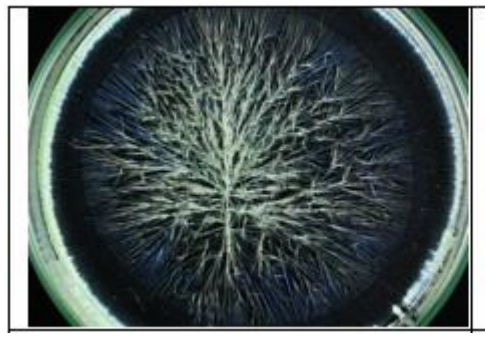

a

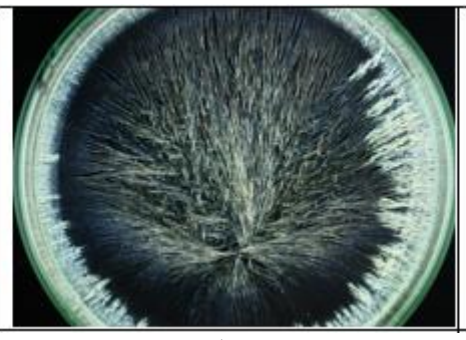

b

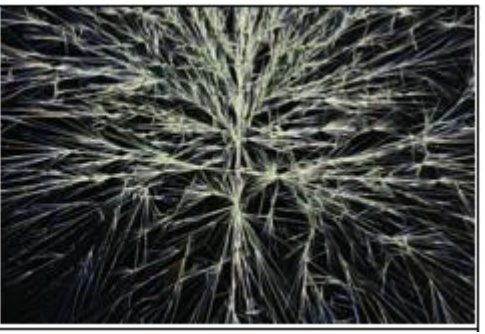

c

Fig. 4a. Specific less coordinated pattern (SLCP) for Calimanesti 7; $0.07 \mathrm{~g} / 4.6 \mathrm{~mL} / 0,4 \mathrm{~mL}$ (DCC/mineral water/bidistilled water per plate; Fig. 4b. SLCP for Caciulata $2 ; 0.07$ g/4,6LL/0.4 mL (DCC/mineral water/bidistilled water per plate;

Fig. 4c. Detail Figure 4a

\section{Conclusions}

The biocrystallization with DCC test can differentiate between the three mineral medicinal waters categories. Our work can mark the beginning of the use of biocrystallization in the study of medicinal waters.

In this study we observed for the first time the specific biocrystallization patterns for some Romanian mineral and medicinal waters. These results can help for a better understanding of the influence of the various organic additives like herbs and food extracts, human or animal blood or tissues, because these organisms are containing minerals.

The observed patterns can be generated and dependent on chemical waters compositions but we don't know what mechanisms are involved and if the chemical composition can totally explained this phenomenon.

Acknowledges: This work was supported by the Fares Bio Vital Laboratories. The funding laboratories had no role in study design, in the collection, analysis and interpretation of data, in the writing of the report and in the decision to submit the paper for publication. This publication is part of the PhD Thesis of the first author.

\section{References}

1. FLEURY, V., Nature, 390, 13,1997, p. 145-148

2. SHIBATA, T., TAKAKUWA, Y., TANAKA, A. J. Tokyo Wom Med Univ 6-7, 1998, p. 358-369,

3. ANDERSEN, J.O. LAURSEN, J., KØLSTER P., Elemente d. N., 68, 1998, p. 3-15

4. REITER G., BARTH J.G., Elemente d. N., 2010, 92, p. 30-61.

5. KAHL J., BUSSCHER, N., PLOEGER A., BAH, 2010, 27, p. 81-86

6. MARSZALEK, K., DOESBURG, P., STARZONEK, S., SZCZEPANSKA, J., WOZNIAK, L., LORENZO, J.M., SKAPSKA, S., RZOSKA,

S., BARBA F. J., Journal of CO2 Utilization, 2018, p.1-11

7. BALI, S., FULZELE, R. R., Int J Med Res Prof., 3(2), 2017, p. 410-413,

8. BALI, S., MARATHE, R.R. Int Arch BioMed Clin Res.;3(2), 2017, p. 46-49.

9. MEHROTRA, H., SADIQ, H., ANJUM, R., GOYAL, P., KASANA, P., SHAIKH, S.M, IJSR., 2017, p. 6-10

10. CHARPENTIER, D., BARTH, J.G., COCUDE, M. Colloque cristallisations sensibles (1998): Ministère de l'Economie, des Finances et de l'Industrie, Paris, 1998, p. 29-34

11. BARTH, J.G., Elemente d. N., 66, 1997, p.16-42

12. BARTH, J.G., ROUSSAUX, J., SUPPAN, K., ROSA DOS SANTOS, S., Elemente d. N.; 94, 2011, p. 69-99.

13. BUSSCHER, N., KAHL, J., DOESBURG, P., MERGARDT G., PLOEGER, A., J., Colloid Interface Sci., 344, (2), 2010, p. 556

14. BUSSCHER, N. DOESBURG, P., MERGARDT, G., SOKOL, A., KAHL, J., PLOEGER, A., Heliyon 4 e01102., 2018, p. 2-17

15. BARTH J.G., 2004, Elemente d. N., 81, 2004, p.23-39.

16. KAHL, J., BUSSCHER, N., DOESBURG, P., MERGARDT, G., WILL, F., SCHULZOVA, V., HAJSLOVA, J., PLOEGER, A., Food Anal. Methods, 2016, 575-6

17. FRITZ, J., ATHMANN M., MEISSNER, G., KAUER, R., KOPKE, U., BAH, 33, 2017, p.195-213

18. FRITZ, J., ATHMANN, M., ANDERSEN, J.O., DOESBURG, P., GEIER, U., MERGARDT, G. BAH, 35, 2019, p. 21-32

19. KAHL, J., BUSSCHER, N., MERGARDT, G., ANDERSEN, J. O., DOESBURG, P., ARLAI, A., PLOEGER, A., Food Anal. Methods, 8 (10), 2015, p. 2533

20. POPOVIC-VRANJEŠ, A., LOPICIC-VASIĆ, T., GRUBJEŠIĆ, G., KRSTOVIĆ, S., LUKAČ, D., KRALJ, A., GEIER, U., Mljekarstvo 66 (4), 2016, p. 262

21. CÎMPEAN, C., BALINT, L., MENCINICOPSCHI, G., BALINT, R., MENCINICOPSCHI, C.I., KISS, C., HOŢIU, C., Agro Buletin AGIR 2011,8, p. 12

22. PFEIFFER E., Sensitive crystallisation processes, Steiner Books, Stuttgart, 1968, p. 20-36

23. SELAWRY, A., Tipuri funcţionale ale metalelor în psihologie si medicina, Ed. Triade, Cluj-Napoca, 2008 p. $443-469$

24. ANDERSEN, J.-O., HENRIKSEN, C., LAURSEN, J., NIELSEN, A., Comput. Electron. Agric. 22, 1999, p. 51

25. KAHL, J. Habilitationsschrift, Universitat Kassel., 2007

26. MEELURSARN, A. PhD thesis, University of Kassel., 2007,

27. DOESBURG, P., ANDREAS, F., NIEROP, M:. COMPAG, 90, 2013, p. 63-67 
28. HUBER, M., ANDERSEN, J.-O., KAHL, J., BUSSCHER, N., DOESBURG, P., MERGARDT, G., KRETSCHMER, S., ZALECKA, A., MEELURSARN, A., PLOEGER, A., NIEROP, D., VAN DE VIJVER, L., BAARS, E., 2010. BAH 27, p. 25-40.

29. KAHL, J., BUSSCHER, N., DOESBURG, P., MERGARDT, G., HUBER, M., PLOEGER, A., 2009. Eur. Food Res. Technol. 229, p. 175178.

30. BUSSCHER, N., KAHL, J., ANDERSEN, J.-O., HUBER, M., MERGARDT, G., DOESBURG, P., PAULSEN, M. , PLOEGER, A., BAH, 27, 2010, p. $1-23$

31. DOESBURG, P., HUBER, M., ANDERSEN, J.-O., ATHMANN, M., VAN DER BIE, G., FRITZ, J., GEIER, U., HOEKMAN, J., KAHL, J., MERGARDT G., BUSSCHER, N. , BAH, 31 (2), 2015, p.128-145

32. FERU, A., Ghidul apelor minerale naturale. Patronatul Apemin, Bucuresti, 2012. P. 4-8

33. STOICESCU C., MUNTEANU L., Factorii naturali de cura din principalele statiuni balneoclimaterice din Romania. Farmacodinamia si folosirea lor in scopuri terapeutice., Ed. Sport-Turism, Bucuresti, 1976, p. 110-118

34. MUNTEANU, C., Ape minerale terapeutice, Ed. Balneara, Bucuresti, 2013, p. 5-8

35. SELAWRY, A; SELAWRY, O., Die Kupferchlorid - Kristallisation in Naturwissenschaft und Medizin, Gustav Fischer Verlag, Stuttgart, 1957, p. 152

36. TESSON, M.F., Cristaux sensible - contribution theoretique et pratique a une science du vivant, Paris, 2006, p. 25-46

37. Engquist, M., Gestatltkrafte des Lebendigen, Vittorio Klostermann, Frankfurt am Main, 1978, p. 31, 41-42

$\overline{\text { Manuscript received: } 15.04 .2019}$ 